\title{
Efficacy and complications of neurosurgical treatment of acromegaly
}

\author{
Anna Krzentowska-Korek • \\ Filip Gołkowski • Agata Bałdys-Waligórska • \\ Alicja Hubalewska-Dydejczyk
}

Published online: 25 November 2010

(C) The Author(s) 2010. This article is published with open access at Springerlink.com

\begin{abstract}
The aim of the study was to evaluate the frequency of occurrence of pituitary failure following neurosurgery and the efficacy of transsphenoidal tumour resection in acromegalic patients. We retrospectively evaluated 85 patients (60 female and 25 male), of mean age $43.9 \pm 13.2$ years, treated by transsphenoidal neurosurgery. Macroadenoma and microadenoma of pituitary were found in $66(77.6 \%)$ and $19(22.4 \%)$ of these patients, respectively. Criteria of cure following neurosurgery were: basal $\mathrm{GH}<2.5 \mu \mathrm{g} / \mathrm{l}, \mathrm{GH}$ at $120 \mathrm{~min}$ in OGTT $<1.0 \mu \mathrm{g} / \mathrm{l}$ and serum concentration of IGF-1 within normal ranges for age and sex. After surgery 32 patients (37.6\%) were cured and 53 patients $(62.4 \%)$ required somatostatin analogue treatment. In patients cured by surgery, lower levels of basal GH $(P<0.05)$, IGF-1 $(P<0.001)$, GH at $120 \mathrm{~min}$ in OGTT and smaller size of pituitary tumour $(P<0.05)$ were found at diagnosis, as compared to patients in whom surgery was unsuccessful. Significant correlation between basal serum level of $\mathrm{GH}$ at diagnosis and size of pituitary tumour was found $(P<0.001)$. Invasive tumours were found in 45 of $53(84.9 \%)$ patients not cured and in only 8 of $32(25.0 \%)$ patients cured $(P<0.001)$. Impaired function of pituitary anterior lobe after surgery was observed in $30 \%$ and $4 \%$ of patients with macro- and microadenoma, respectively $(P<0.05)$. The efficacy of neurosurgery is affected by concentration of basal serum GH and IGF-1, GH at $120 \mathrm{~min}$ in OGTT, tumour size and invasiveness. Hypopituitarism after surgery is more frequent in patients with macroadenoma. Pituitary insufficiency, as a consequence of surgery,
\end{abstract}

A. Krzentowska-Korek · F. Gołkowski ( $\square)$.

A. Bałdys-Waligórska · A. Hubalewska-Dydejczyk

Department of Endocrinology, Jagiellonian University Medical

College, Kopernika 17, 31-501 Kraków, Poland

e-mail: filip.golkowski@onet.eu was found in $21 \%$ of patients with normal pituitary function prior to operation.

Keywords Pituitary - Acromegaly · GH · IGF-1 · Neurosurgery $\cdot$ Hypopituitarism

\section{Introduction}

Acromegaly is a rare chronic disease occurring with a population prevalence of 60 per million and incidence of 3-4 per million a year [1]. In almost all cases, it is caused by growth hormone $(\mathrm{GH})$ - secreting pituitary adenoma, producing an excess of GH. In turn, growth hormone stimulates production of insulin-like growth factor-1 (IGF-1). Therefore, in acromegaly, its concentration is elevated. Progressive somatic disfigurement (mainly involving face and extremities) and systemic complications such as arterial hypertension, cardiomyopathy, congestive heart failure, arrhythmias, sleep apnea and ventilatory dysfunction, multinodular goitre, menstrual irregularities, hyperprolactinaemia, diabetes mellitus, arthropathy, peripheral neuropathy, colon polyps are the main clinical manifestations of acromegaly $[2,3]$. Increased risk of cancer (particularly colon cancer) is being considered [4-6]. Acromegaly is associated with significant morbidity and increased mortality as compared to the general population [1,7-9]. The mortality rate for uncontrolled disease activity is 2-4 times higher than that of the general population, principally because of higher risk of cardiovascular disease [8]. This mortality ratio can be decreased if the elevated GH and IGF-1 levels are successfully normalized. The criteria for diagnosing acromegaly are: elevated serum GH and IGF-1 concentration above normal range for age and gender, and no inhibition of $\mathrm{GH}$ concentration in OGTT (75 g of glucose) below $1.0 \mu \mathrm{g} / \mathrm{l}$. 
Transsphenoidal resection of pituitary adenoma still remains the primary therapy for most patients with acromegaly. If surgery fails to correct GH/IGF-1 hypersecretion, medical treatment with somatostatin analogues, dopaminergic agonists and/or radiotherapy can be applied. A GH antagonist (pegvisomant) may be used in patients resistant to somatostatin analogues [11]. The therapeutic goals in acromegaly are to eliminate morbidity and to reduce mortality. Both objectives can be achieved by removing tumour mass or controlling its growth. The definitions of "cure" and disease control are: basal GH concentration below $2.5 \mu \mathrm{g} / \mathrm{l}$, nadir $\mathrm{GH}$ concentration at $120 \mathrm{~min}$ of OGTT below $1.0 \mu \mathrm{g} / \mathrm{l}$ and normal IGF-1 for age and gender [10].

The aim of this study was to examine the incidence rate of pituitary failure following neurosurgery in acromegalic patients. The dependence of the efficacy of transsphenoidal tumour resection on pre-operative factors, such as tumour size and serum GH and IGF-1 concentration, were also evaluated.

\section{Materials and methods}

Our study concerned acromegalic patients treated at the Department of Endocrinology, Jagiellonian University Hospital in Krakow, a regional centre for acromegalic patients, between 1986 and 2009. Of these, 85 patients (60 female and 25 male), of mean age $43.9 \pm 13.2$ years, were treated by transsphenoidal neurosurgery. In all 85 patients no somatostatin analogue treatment nor radiotherapy had preceded neurosurgery. Macroadenoma of the hypophysis was found in $66(77.6 \%)$ patients, while microadenoma was found in $19(22.3 \%)$ patients. Acromegaly was usually diagnosed within 7-10 years of the onset of disease. The mean age of patients at diagnosis of acromegaly was $43.9 \pm 13.2$ years. Two groups of patients were analysed: those cured by surgery and those in whom surgery was not successful.

The serum concentration of GH and IGF-1 was measured using IRMA (DiaSorin) and RIA (Biosource) methods, respectively. The concentration of pituitary and thyroid hormones before and after surgery were estimated. Measurements of ACTH, FSH, LH, TSH serum concentrations were performed using immunoradiometric assay (IRMA), $\mathrm{fT}_{3}$ and $\mathrm{fT}_{4}$ serum concentration was measured by electrochemiluminescent (ECL) method. The prevalence of diabetes insipidus was stated based on plasma and urine osmolality. In 45 of the 85 patients studied full preoperative pituitary function evaluation was completed. The effect of surgery on pituitary hormonal sufficiency was assessed in this subgroup.
For statistical analysis, basic statistics, Shapiro-Wilk, U Mann-Whitney and $\chi^{2}$ tests of the Statistica v.8.0 package were used.

\section{Results}

In the 85 acromegalic patients a higher frequency of macroadenoma $(66 / 85,77.6 \%)$ was observed. The size of pituitary adenoma at diagnosis in patients treated by neurosurgery is shown in Table 1 . The mean basal serum GH concentration prior to treatment was $33.3 \pm 40.5 \mu \mathrm{g} / \mathrm{l}$, mean concentration of $\mathrm{GH}$ at $120 \mathrm{~min}$ in OGTT was $20.3 \pm 31.1 \mu \mathrm{g} / \mathrm{l}$, and mean level of IGF-1 was $818.8 \pm$ $346.9 \mathrm{ng} / \mathrm{ml}$. After surgery 32 patients (38\%) were cured and 53 patients $(62 \%)$ required further treatment with somatostatin analogues. The efficacy of surgery was dependent on the size of pituitary adenoma (Fig. 1).

In $45(85 \%)$ of not cured patients and in $8(25 \%)$ patients in whom surgery was successful invasive tumour was identified on preoperative imaging (Fig. 2), which affected the outcome of surgery $(P<0.001)$.

A high frequency of mixed adenoma in acromegalic patients was observed (monohormonal adenoma 29.6\%, polyhormonal adenoma $70.5 \%$ ).

The prevalence of pituitary adenoma secreting other hormones than GH was as follows: PRL-56.8\% of acromegalic patients, ACTH-20.5\% of these patients, FSH$15.9 \%, \alpha$-subunit-11.6\%, TSH- $11.4 \%$ and LH- $6.82 \%$ of

Table 1 Size of pituitary adenoma at diagnosis in patients treated by neurosurgery $(n=85)$

\begin{tabular}{llr}
\hline Tumour size $[\mathrm{mm}]$ & $N$ & $\%$ \\
\hline$\leq 10$ & 19 & 22.4 \\
$11-20$ & 40 & 47.1 \\
$21-30$ & 16 & 18.8 \\
$31-40$ & 6 & 7.1 \\
$>40$ & 4 & 4.7 \\
\hline
\end{tabular}

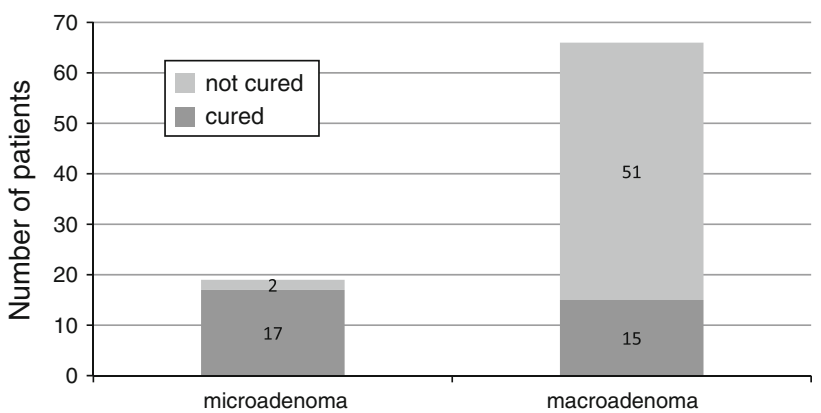

Fig. 1 The efficacy of surgery in micro- and macroadenoma of the pituitary 
Fig. 2 Tumour invasiveness, as based on MRI imaging, in acromegalic patients not cured and cured after transsphenoidal surgery
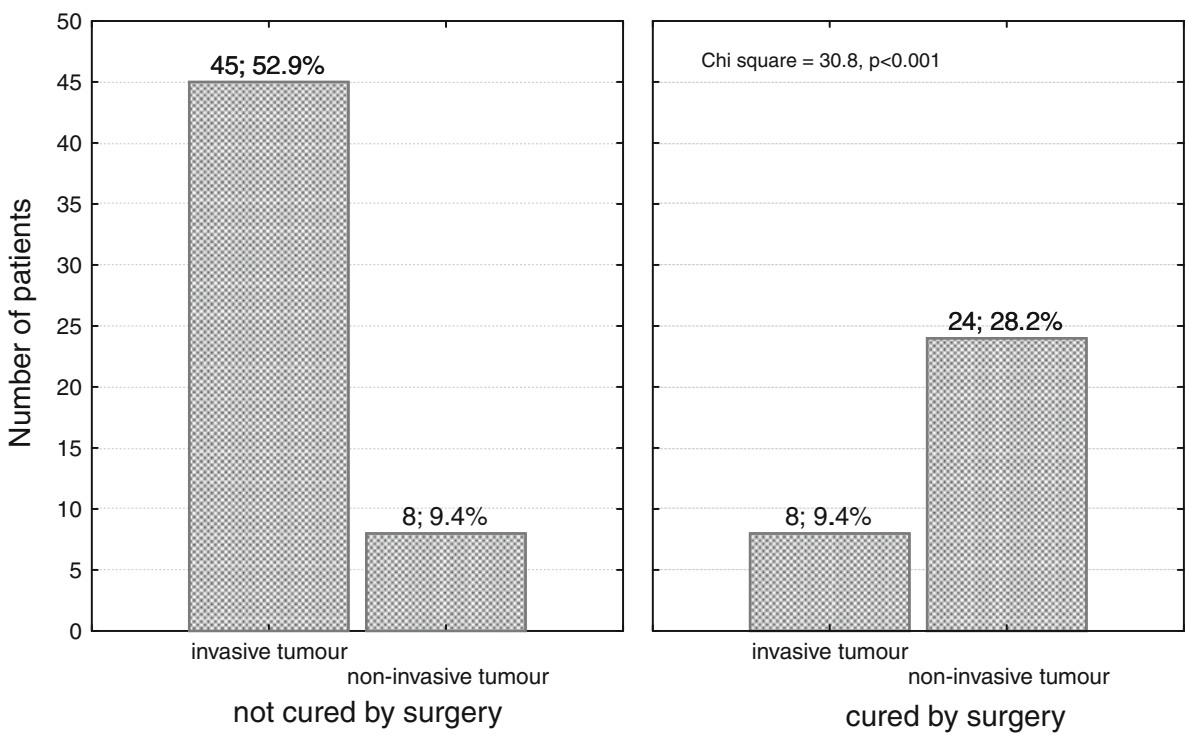

Table 2 The relationship between the pituitary adenoma size and the frequency of deficient function of anterior lobe of pituitary after surgery

\begin{tabular}{llcl}
\hline Size of adenoma & $\begin{array}{l}\text { Normal } \\
\text { function } n(\%)\end{array}$ & $\begin{array}{l}\text { Impaired } \\
\text { function } n(\%)\end{array}$ & $\begin{array}{l}\text { Total } \\
n(\%)\end{array}$ \\
\hline Microadenoma & $16(18.8)$ & $3(3.5)$ & $19(22.4)$ \\
Macroadenoma & $36(42.4)$ & $30(35.3)$ & $66(77.6)$ \\
Total & $52(61.1)$ & $33(38.8)$ & $85(100)$ \\
\hline
\end{tabular}

Pearson's $\chi^{2}$ test: $5.466, P<0.05$

these patients. No difference in surgery outcome between patients with mono and plurihormonal tumours $(P>0.05)$ was found. Permanent (over 3 months) impairment of posterior lobe function (diabetes insipidus) was observed in 16.7 and $22.2 \%$ patients with macro- and microadenoma, respectively.

Impaired function of pituitary-adrenal, pituitary-thyroid and pituitary-gonadal axis were proven in 24 (28.2\%), 22 (25.9\%) and $18(21.1 \%)$ studied patients, respectively.

Significant difference $(P<0.05)$ between frequency of impaired function of the pituitary anterior lobe in patients with micro- and macroadenoma was observed (Table 2). In the case of the posterior lobe, no such relation was observed $(P>0.05)$.

Normal pituitary function prior to surgery was observed in thirty-three of the 45 patients in whom evaluation of pituitary hormonal sufficiency was complete. Following surgery, seven $(21 \%)$ of these 33 patients were diagnosed as having hypopituitarism, poly- or monoaxial. In all patients with hypopituitarism the adrenal axis was impaired, which was the most frequent sequel (Fig. 3).

There were 12 patients with poly- or mono-axial hypopituitarism prior to surgery. Gonadal monoaxial insufficiency was the most frequent failure found prior to surgery

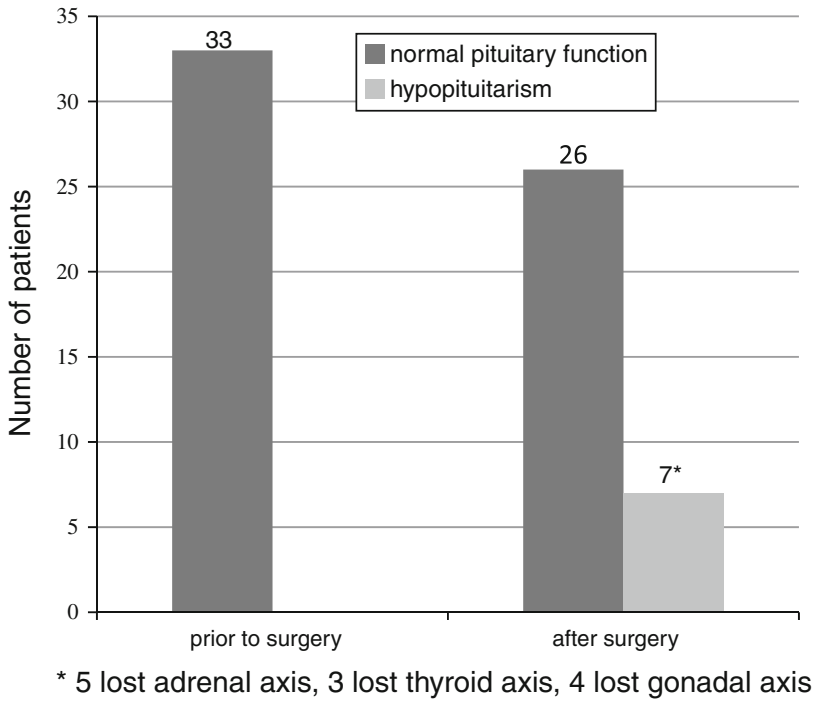

Fig. 3 Normal pituitary function and hypopituitarism after transsphenoidal surgery in patients with sufficient pituitary function prior to operation

(11 patients). In one case we diagnosed thyroidal monoaxial pituitary failure prior to surgery.

In 5 out of 12 patients with poly- or mono-axial hypopituitarism prior to surgery, worsening of pituitary function was found post-surgery, while in 1 patient no change was observed. In 6 patients normal sufficient pituitary function was restored (Fig. 4). Worsening of pituitary function was defined as failure of a higher number of hormonal axes than prior to surgery.

A statistically significant correlation between basal serum GH concentration and the size (largest diameter) of pituitary tumour was found $(P<0.001)$.

We compared two groups of patients, cured and not cured by surgery. At diagnosis, statistically significant 


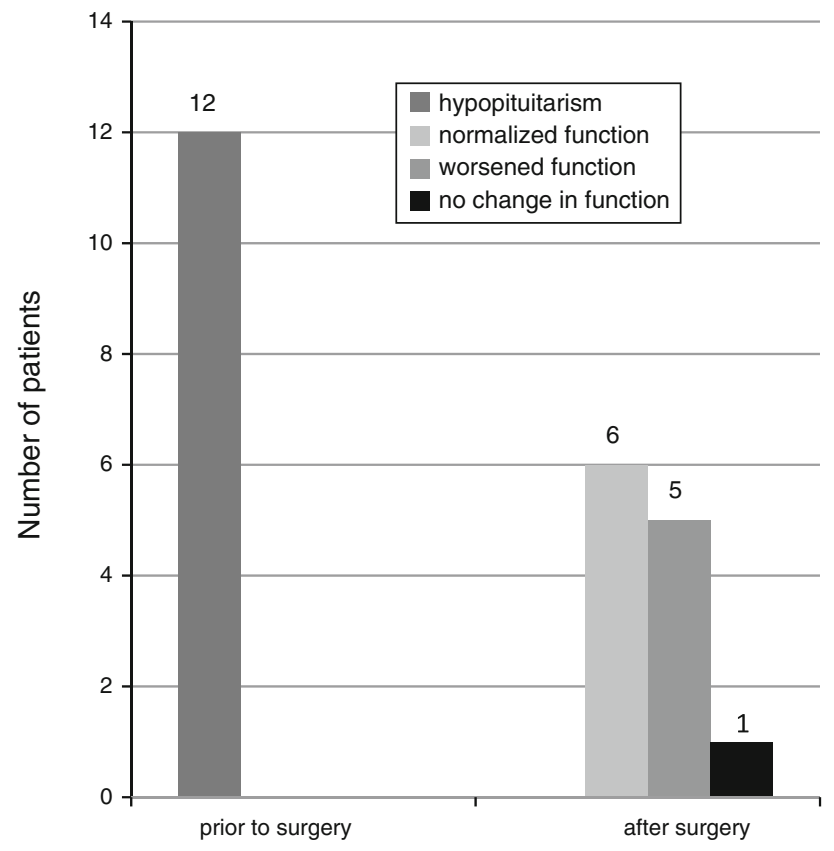

Fig. 4 Changes in pituitary hormonal function after surgery in patients with hypopituitarism prior to operation

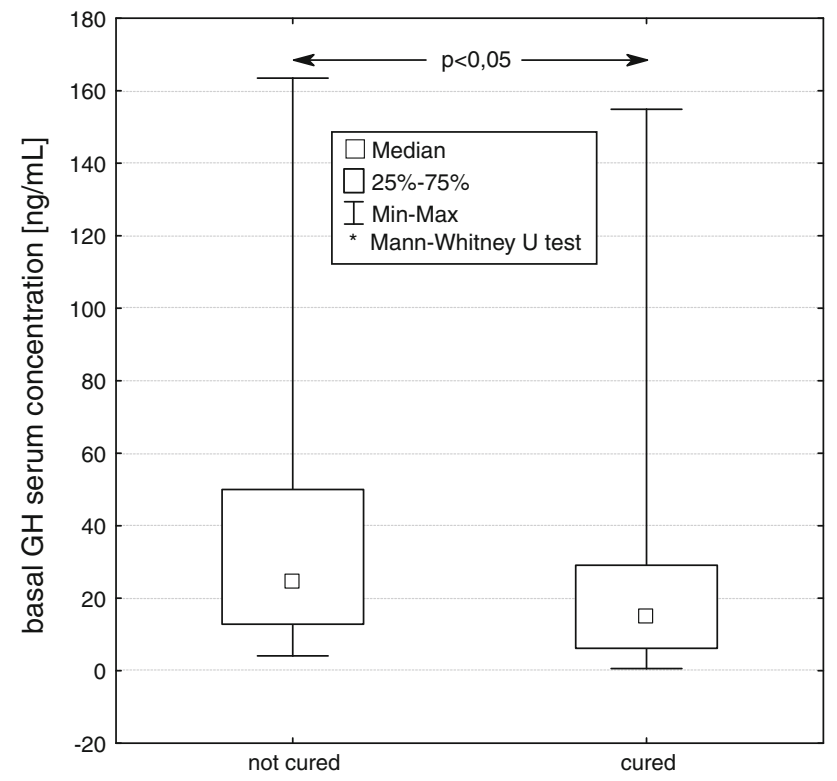

Fig. 5 Basal serum GH concentration at diagnosis in patients not cured and cured by pituitary adenoma surgery

differences between median values of basal GH concentration $(P<0.05)$, GH concentration at $120 \mathrm{~min}$ in OGTT $(P<0.05)$, IGF-1 concentration $(P<0.001)$ and the size (largest diameter) of pituitary tumour $(P<0.05)$, were found between these groups. (Figs. 5, 6, 7, 8).

The mean values $(\mathrm{X} \pm \mathrm{SD})$ of $\mathrm{GH}$ concentration in groups of patients cured and not cured were $29.3 \pm 39.5$ and $36.6 \pm 33.9 \mu \mathrm{g} / \mathrm{l}$, respectively. The mean values of

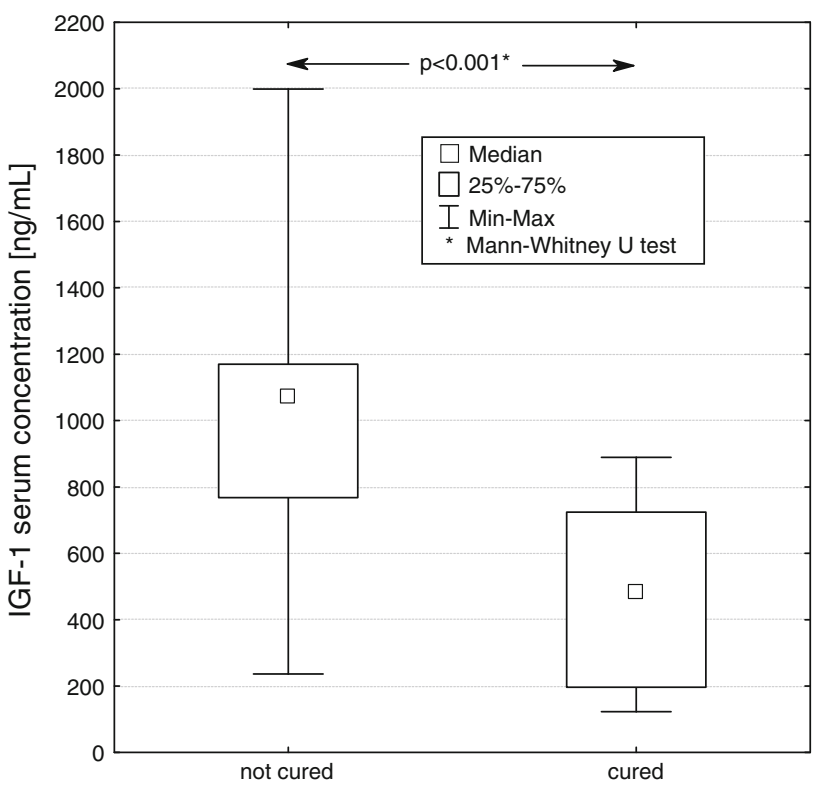

Fig. 6 Basal serum IGF-1 concentration at diagnosis in patients not cured and cured by pituitary adenoma surgery

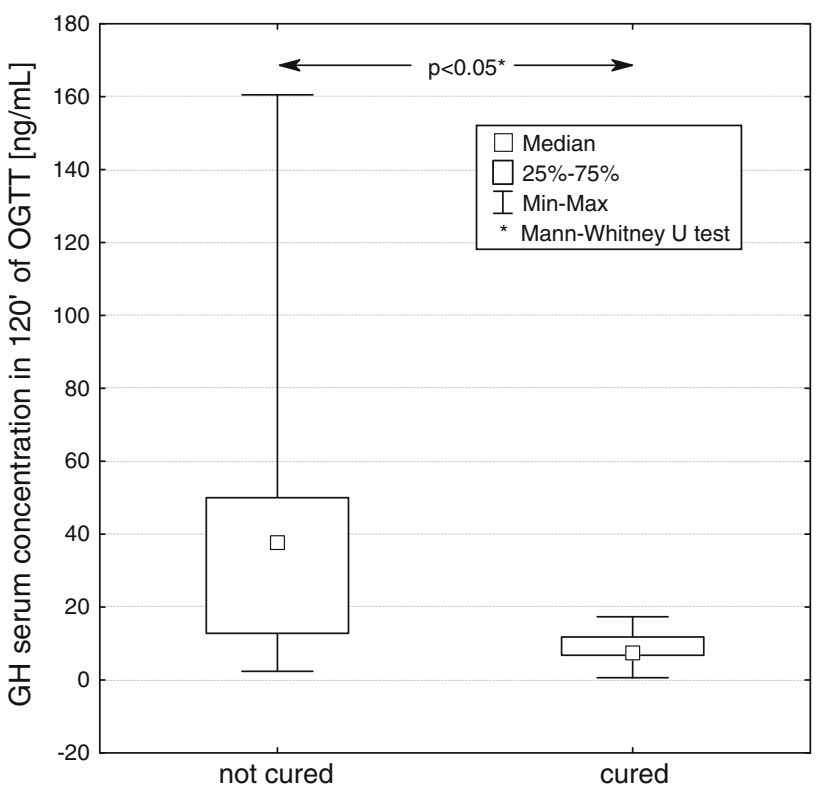

Fig. $7 \mathrm{GH}$ concentration at $120 \mathrm{~min}$ of OGTT in patients not cured and cured by pituitary adenoma surgery

IGF-1 concentration in groups of patients cured and not cured were $489.1 \pm 264.0$ and $981.1 \pm 361.9 \mathrm{ng} / \mathrm{ml}$, respectively. The average concentrations of $\mathrm{GH}$ at $120 \mathrm{~min}$ of OGTT in these groups of patients were $8.7 \pm 6.2$ and $48.1 \pm 49.7 \mu \mathrm{g} / \mathrm{l}$, respectively.

The mean values of the largest diameter of pituitary adenoma in the group of patients cured by surgery and the group of patients in whom surgery was unsuccessful, were $10.8 \pm 10.0$ and $15.5 \pm 12.6 \mathrm{~mm}$, respectively. Significant 


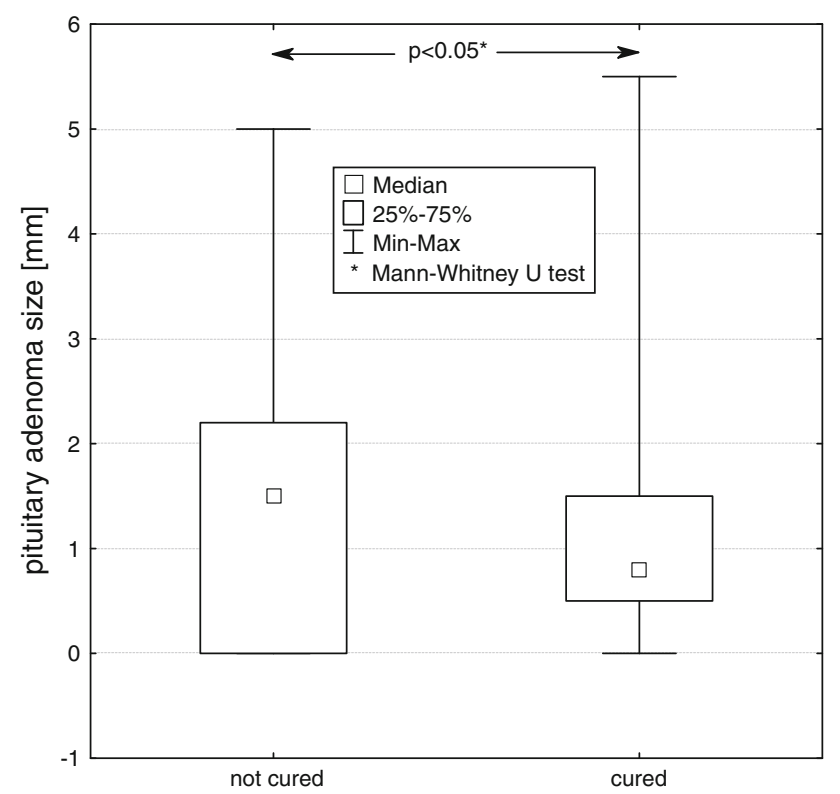

Fig. 8 Size (largest diameter) of pituitary adenoma at diagnosis in patients not cured and cured by pituitary adenoma surgery

influence of the size of pituitary adenoma on neurosurgery outcome was found $(P<0.05)$.

\section{Discussion}

Acromegaly is a rare disease caused by growth hormone excess, in majority of cases due to a $\mathrm{GH}$ - secreting pituitary adenoma. The therapeutic goals in acromegaly are to eliminate morbidity and to reduce mortality. These can be achieved by removing tumour mass (transsphenoidal surgery) or by controlling its growth (somatostatin analogues, dopaminergic agonists, GH antagonist, and/or radiotherapy) [11-14].

In our study we observed that factors, such as basal GH concentration, GH concentration at $120 \mathrm{~min}$. of OGTT, IGF-1 concentration as well as the size of pituitary tumour prior to surgery, significantly influence the degree of disease control after neurosurgery.

In microadenoma the efficiency of neurosurgical treatment ranges between $61-91 \%$ of all cases operated on, as compared to macroadenoma $23-53 \%$, in which the success of surgery depends on the tumour size, its location and on initial concentration of GH [15-16].

In our studied group, the results of surgery in patients with larger pituitary tumours were worse as compared to patients with microadenoma. Patients with macroadenoma had higher basal level of GH than $2.5 \mu \mathrm{g} / \mathrm{l}$, IGF-1 above the normal limits for age and gender, so did not meet the criteria for cure. A statistically significant difference in the size of tumour (the largest diameter) between groups of cured and not cured patients was found.

The study of Barker et al. [17] and Ciric et al. [18] revealed that transsphenoidal surgery of pituitary adenoma involved mortality of around $0.9 \%$ in the perisurgery period.

According to Salaun et al. [19], the poor prognosis factors are: young age, prior to surgery growth hormone level of over $50 \mathrm{ng} / \mathrm{ml}$, invasive adenomas, monohormonal status in immunocytochemistry and lack of decrease in postoperative growth hormone level during the glucose tolerance test. In our study, the monohormonal status as a prognostic factor was not confirmed.

Hypopituitarism in acromegalic patients may result from compression of the pituitary by the tumour or result from neurosurgical treatment. Therefore, the pituitary function should be estimated in these patients prior to and after surgery.

In our study, impaired function of the anterior lobe of the pituitary was observed more frequently in patients with macroadenoma than in those with microadenoma, unlike the case of impaired function of the posterior lobe after surgery, which was found more frequently in patients with microadenoma than in those with macroadenoma.

According to Tomlinson et al. and Rosen et al. [20, 21], hypopituitarism observed in $10-40 \%$ of acromegaly patients leads to increased mortality rate despite optimal hormonal substitution. In 2009 Sherlock et al. [22] evaluated the influence of radiotherapy, deficient secretion of ACTH and treatment with hydrocortisone $(\mathrm{HC})$ on the mortality rate, observing increased mortality rate in acromegaly patients with ACTH deficiency following radiotherapy. They also observed that administration of high doses of hydrocortisone (over $25 \mathrm{mg}$ per day) corresponded with increased mortality, compared with administration of lower doses of this medication. Based on this observation they stated that the dose of hydrocortisone has to be carefully titrated in these patients.

Reported incidence of new hypopituitarism following neurosurgery in $21 \%$ of our patients is possibly due to relatively wide time range when operations were carried out and related to continuously increasing experience of our neurosurgery team. The impact of subspecialization in pituitary surgery on its efficacy is well known [23]. Recently, Gondim et al. (2010) reported pituitary failure in 9 of $67(13.4 \%)$ transsphenoidally operated patients with acromegaly [24].

Rieger et al. examined 44 acromegaly patients who underwent surgery [25]. In 25 of these patients invasion of the sphenoid sinus was found. Interestingly, the level of GH prior to surgery appeared to be a more important indicator of tumour invasiveness than IGF-1 concentration. The high GH concentration prior to and after surgery 
correlated with suprasellar growth of the tumour. Thus, according to these authors, GH concentration should be considered as a prognostic factor in selecting further treatment of pituitary adenoma.

\section{Conclusion}

Based on our observations, we found that the efficacy of transsphenoidal surgery in acromegalic patients was affected by basal serum GH and IGF-1 concentration, GH concentration at $120 \mathrm{~min}$ in OGTT, tumour size, and invasiveness. Hypopituitarism after surgery is more frequent in patients with macroadenoma. Following surgery, pituitary insufficiency was found in $21 \%$ of patients with normal pituitary function prior to operation. In some $50 \%$ of patients with monoaxial insufficiency of pituitary prior to surgery, restoration of pituitary function was observed.

\section{Conflict of interest None.}

Open Access This article is distributed under the terms of the Creative Commons Attribution Noncommercial License which permits any noncommercial use, distribution, and reproduction in any medium, provided the original author(s) and source are credited.

\section{References}

1. Holdaway IM, Rajasoorya C (1999) Epidemiology of acromegaly. Pituitary 2:29-41

2. Mestron A, Webb SM, Astorga R et al (2004) Epidemiology clinical characteristics, outcome, morbidity and mortality in acromegaly based on the Spanish acromegaly registry (Registro Espaňol de Acromegalia, REA). Eur J Endocrinol 151:439-446

3. Colao A, Ferone D, Marzullo P, Lombardi G (2004) Systemic complications of acromegaly: epidemiology, pathogenesis and management. Endocr Rev 25:102-152

4. Jenkins PJ, Besser M (2001) Clinical perspective: acromegaly and cancer: a problem. J Clin Endocrinol Metab 86:2935-2941

5. Jenkins PJ (2006) Cancers associated with acromegaly. Neuroendocrinology 83:218-223

6. Rokkas T, Pistiolas D, Sechopoulos P, Margantinis G, Koukoulis G (2008) Risk of colorectal neoplasm in patients with acromegaly: a meta-analysis. World J Gastroenterol 14:3484-3489

7. Loeper S, Ezzat S (2008) Acromegaly: rethinking the cancer risk. Rev Endocrinol Metab Disord 9:41-58

8. Orme SM, McNally RJ, Cartwright RA, Belchetz PE (1998) Mortality and cancer incidence in acromegaly; a retrospective cohort study. United Kingdom acromegaly study group. J Clin Endocrinol Metab 83:2730-2734
9. Holdaway IM, Rajasoorya RC, Gamble GD (2004) Factors influencing mortality in acromegaly. J Clin Endocrinol Metab 89:667-674

10. Giustina A, Barkan A, Casanueva FF et al (2000) Criteria for cure of acromegaly: a consensus statement. J Clin Endocrinol Metab 85:526-529

11. Chanson P, Salenave S (2008) Acromegaly. Orphanet J Rare Dis 25:17

12. Lüdecke DK, Abe T (2006) Transsphenoidal microsurgery for newly diagnosed acromegaly: A personal view after more than 1,000 operations. Neuroendocrinology 83:230-239

13. Melmed S, Casaneuva FF, Cavagnini F et al (2002) Consensus. Guidelines for acromegaly management. J Clin Endocrinol Metab 87:4054-4058

14. Freda PU, Wardlaw S1, Post KD (1998) Long-term endocrinologic follow-up after transsphenoidal surgery for acromegaly. J Neurosurg 89:353-358

15. Nomikos P, Buchfelder M, Fahlbush R et al (2005) The outcome of surgery in 668 patients with acromegaly using current criteria of biochemical "cure". Eur J Endocrinol 152:379-387

16. Swearingen B, Barker FG, Katznelson L, Biller BM, Grinspoon S, Klibanski A, Moayeri N, Black PM, Zevas NT (1998) Longterm mortality after transsphenoidal surgery and adjunctive therapy for acromegaly. J Clin Endocrinol Metab 83:3419-3426

17. Barker FG, Klibanski A, Swearingen B (2003) Transsphenoidal surgery for pituitary tumors in the United States, 1996-2000: mortality, morbidity, and the effects of hospital and surgeon volume. J Clin Endocrinol Metab 88:4709-4719

18. Ciric I, Ragin A, Baumgartner C, Pierce D (1997) Complications of transsphenoidal surgery: results of a national survey, review of the literature, and personal experience. Neurosurgery 40:225-236

19. Salaun C, Foubert L, Vialatou M, Kujas M, Turpin G (1999) Prognostic factors in the surgical management of acromegaly. Ann Med Intern 150:195-198

20. Tomlinson JW, Holden N, Hills RK, Wheatley K, Clayton RN, Bates AS, Sheppard MC, Stewart PM (2001) Association between premature mortality and hypopituitarism. West midlands prospective hypopituitary study group. Lancet 357:425-431

21. Rosen T, Bengtsson BA (1990) Premature mortality due to cardiovascular disease in hypopituitarism. Lancet 336:285-288

22. Sherlock M, Reulen RC, Alonso AA, Ayuk J, Clayton RN, Sheppard MC, Hawkins MM, Bates AS, Stewart PM (2009) ACTH deficiency, higher doses of hydrocortisone replacement, and radiotherapy are independent predictors of mortality in patients with acromegaly. J Clin Endocrinol Metab 94:4216-4223

23. Leach P, Abou-Zeid AH, Kearney T, Davis J, Trainer PJ, Gnanalingham KK (2010) Endoscopic transsphenoidal pituitary surgery: evidence of an operative learning curve. Neurosurgery 67:1205-1212

24. Gondim JA, Alemida JP, de Albuquerque LA, Gomes E, Schops M, Ferraz T (2010) Pure endoscopic transsphenoidal surgery for treatment of acromegaly: results of 67 cases treated in a pituitary center. Neurosurg Focus 39(4):1-6 doi:10.3171/2010.7.FOCUS10167

25. Rieger A, Rainov NG, Ebel H, Sanchin L, Shibib K, Helfrich C, Hoffmann O, Burkert W (1997) Factors predicting pituitary adenoma invasiveness in acromegalic patients. Neurosurg Rev 20:182-187 